\title{
Delivery and postpartum care in Rio Branco in the northern state of Acre, Brazil: a population- based survey
}

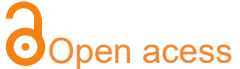

${ }^{1}$ Enfermeira, Doutora, Universidade Federal do Acre - Rio Branco - AC Brasil

${ }^{2}$ Nutricionista, Doutor, Universidade Federal do Acre - Rio Branco - AC Brasil

${ }^{3}$ Enfermeira, Mestre, Hospital das Clínicas - Rio Branco - AC - Brasil

\section{Corresponding author:} andreaufac@bol.com.br

Manuscript received: Setember 2017 Manuscript accepted: November 2017 Version of record online: March 2018

\author{
Andréa Ramos da Silva Bessa1, Leila Maria Geromel Dotto', \\ Margarida de Aquino Cunha ${ }^{1}$, Pascoal Torres Muniz², Suelen \\ de Oliveira Cavalcante ${ }^{3}$
}

\begin{abstract}
Introduction: Pregnancy can be associated with health risks for both the mother and infant, and specialised care during the pregnancy, delivery and puerperium periods can help reduce complications for the motherinfant binomial.
\end{abstract}

Objective: To assess the demographic, social and reproductive aspects of delivery and the postpartum period in Rio Branco, Acre, Brazil.

Methods: A population-based cross-sectional survey was conducted via an interview with 552 mothers with children aged 0 to 5 years between 2007 and 2008 . Cluster sampling of the population was performed in two stages (census sectors and domiciles).

Results: The majority of the 552 mothers were multiparous (79.6\%). Around $70 \%$ of pregnancies occurred in teenage mothers. The proportion of caesarean section deliveries was $38.4 \%$ in mothers from urban zones and $28.5 \%$ in those from rural areas, and was higher in mothers who attended private clinics, who self-reported as being Caucasian, and who had a higher educational level. With regard to puerperal complications, mothers who underwent caesarean section had a higher prevalence of hypertension (71.1\%) with an adjusted prevalence ratio of $3.90(95 \% \mathrm{Cl}[2.00$, 7.61]).

Conclusions: The results revealed a high rate of teenage pregnancy, and arterial hypertension was the leading complication during the postpartum period experienced by women who had undergone caesarean section. These findings merit further attention, and should be used to improve the care provided to Rio Branco.

Keywords: natural childbirth, cesarean section, postpartum period. 


\section{INTRODUCTION}

It has been increasingly recognised that childbirth and the immediate postpartum period are vulnerable periods for both the mother and newborn. It is estimated that between $25 \%$ and $45 \%$ of neonatal deaths and $45 \%$ of maternal deaths occur during the first 24 hours after birth $^{1,2}$

Attention to childbirth in Brazil is characterised by high intervention rates, especially caesarean section, ranging from $44 \%{ }^{3}$ to $51.9 \%{ }^{4}$ of all births in the country. The socioeconomic level of the mother and the resulting level of care provided in the private or public sectors determine the degree of intervention during childbirth ${ }^{5}$.

Adequate care for women during childbirth plays a key role in ensuring good outcomes during this process, besides reducing the occurrence of severe maternal morbidity and death ${ }^{6}$.

Most pregnancies and births occur without incident. However, all pregnancies present a risk. About $15 \%$ of all pregnant women experience some form of lifethreatening complication requiring skilled care, and in some cases, successful and safe obstetric intervention can save their lives?.

A study that investigated 4560 births that occurred in a public maternity centre in Goiânia, Goias, Brazil, reported 86 transfers of women (pregnant and postpartum) to intensive care units. Of these women, $52.3 \%$ were nulliparous, $73.3 \%$ belonged to the age group of 19-35 years, $72.4 \%$ underwent a caesarean birth, $81.4 \%$ were transferred during the puerperal period, with $82.6 \%$ of the transfer indications related to obstetric causes. Gestational hypertension disorders accounted for more than half $(57.7 \%)$ of obstetric indications, with eclampsia being the cause in half of these cases ${ }^{8}$.

The greatest challenge for maternal care is its unpredictability, especially at the time of childbirth. Complications that can put a woman and child at risk may

\section{METHODS}

This cross-sectional, population-based study was carried out in the city of Rio Branco, Acre, using data from the Health and Nutrition Survey of Children and Adults of Rio Branco.

Data collection was carried out between 2007 and 2008 , in which information on all pregnancies among women with children aged 0 to 5 years was obtained. To that end, one of the inclusion criteria was that the person who responded to the survey was the biological mother.

The sampling model adopted was clustering with two selection stages (census tracts and domiciles). The census tracts used were the 250 sectors used by the Brazilian Institute of Geography and Statistics (IBGE) for the 2000 census, which included the urban and rural areas of the municipality of Rio Branco. Of these, 35 census tracts, 31 urban and four rural sectors, were selected at random.

In each census tract, a total of 875 households were randomly selected to be surveyed, and mothers of children aged 0 to 5 years who lived in the selected household and accepted to participate in the study by providing their free arise suddenly, so the presence of a qualified professional is essential to ensure that complications are properly managed ${ }^{9}$.

In Brazil, $89 \%$ of deliveries are attended by physicians and $8.3 \%$ by obstetric nurses. However, there is still a significant percentage of women without access to skilled care. These include almost $8 \%$ of mothers in the North of Brazil who had a live birth within the past 5 years, and more than $13 \%$ of those with no schooling. In the North and Northeast regions, deliveries attended by lay midwives represent $5.8 \%$ and $3.6 \%$ of live births, respectively ${ }^{3}$.

Data from the Brazilian National Hospital Based Survey, "Nascer no Brasil", conducted in 2011/2012, revealed that good practices during labour occurred in less than $50 \%$ of women, being less frequent in less developed areas in the North and Northeast, in which obstetric and perinatal indicators are considered the worst in the country ${ }^{4}$

Therefore, recognising the reality of childbirth care in Rio Branco, the capital city of the northern Brazilian state of Acre, is extremely important to identify where and with whom women are giving birth in this municipality, a region with very different health indicators to other regions of the country. We aimed to identify the prevalence of caesarean delivery and the demographics of women who undergo this procedure. This study fills the gap on the characterisation of childbirth care in this municipality. It is also important to identify the complications that affect women during the postpartum period, a critical period in which the risk of mortality is significant.

Thus, the objective of this study was to analyse the characteristics of attention to childbirth and the postpartum period in the city of Rio Branco considering the sociodemographic and reproductive aspects.

and informed consent were eligible for participation in the survey. However, it was observed that only $40 \%$ of the households had children under the age of 5, leading to the need to draw two more samples of equal size.

A total of 2622 households were randomly selected, in which 723 children under the age of 5 were eligible. However, $3 \%$ of the mothers of these children refused to participate in the study. Thus, 552 mothers were interviewed with a total of 648 pregnancies and births, that is, the births of 648 children were analysed.

The data collection instrument included a structured and precoded questionnaire which was used to interview the mothers of children under 5 years old in the participating households.

For this study, the following variables were selected for inclusion in the survey:

-Sociodemographic variables related to the mother: age, schooling, marital status, living area, skin colour, paid activity and number of children;

-Pregnancy-related variables: number of prenatal consultations, woman's age at first pregnancy and at the 
most recent pregnancy, and child death;

-Variables related to childbirth: type of delivery, type of professional who performed the delivery and place of birth (public or private hospital or home);

-Postpartum variables: postpartum complications (haemorrhage, fever, seizure, psychic disorder, hypertension and hospitalisation).

The conditions associated with delivery in Rio Branco were initially analysed in a descriptive way, then the main factors associated with caesarean delivery were investigated. We believed that the attention provided to childbirth would differ between the urban and rural areas of Rio Branco, therefore, we chose to perform the descriptive analysis by area of housing.

Descriptive data analysis was performed to determine the frequency of the studied events. This was followed by estimation of the prevalence ratios of interest

\section{RESULTS}

Concerning the sociodemographic characteristics, the mean age of the mothers interviewed was 26.7 (standard deviation 6.8) years, with a predominance of women in the 25-34 (45.8\%) and 14-24 (42.6\%) year age groups. About $73 \%$ lived with a partner and $65.8 \%$ were housewives. Regarding schooling, $42.7 \%$ of the women had between 5-9 years of schooling, $32.8 \%$ between 10 15 years, and $24.6 \%$ with less than 5 years of schooling. In regard to skin colour, $67.5 \%$ defined themselves as brown, $18.0 \%$ as black and $14.5 \%$ as white.

Regarding the reproductive history of the mothers interviewed, the majority were multiparous (79.6\%). The mean age at which women had their first pregnancy was 18.9 (standard deviation 6.3) years in urban areas and 18.0 (standard deviation 3.6) years in rural areas $(\mathrm{p}=0.321)$. using Poisson regression. Initially, the univariate Poisson regression model was used to select the variables that should compose the multiple model according to the level of statistical significance of entry in the model, which was a p-value of $<0.20$, introduced by the ENTER method in the model. Those that remained presented higher statistical significance $(p<0.05)$. In the data analysis, the Svy tool or STATA survey module were used to correct the results obtained according to the sampling process performed by clusters.

This study was conducted according to the ethical principles of research established by the National Health Council in resolution no. 196/96. The research only began after approval of the project under process no. 23107.00115/2007-22 by the Committee of Ethics in Research at the Federal University of Acre.

The prevalence of home births in Rio Branco was $1.7 \%$, including $3.0 \%$ of women living in rural areas and $5.9 \%$ of those with lower levels of schooling. The accomplishment of labour according to the type of professional evidences the accomplishment of the same with doctors in $70 \%$ of deliveries in the urban area $(64.6 \%$ in the rural area).

Caesarean delivery was performed in $38.4 \%$ of deliveries in urban areas and $28.5 \%$ of those in rural areas. The number of deliveries assisted by midwives was $12.4 \%$ and $23.5 \%$ in urban and rural areas, respectively, and $17.6 \%$ and $11.9 \%$ of deliveries were assisted by nurses, respectively (Table 1 ).

In the urban area, about $70 \%$ of pregnancies occurred in females under 20 years of age, and 10.4\%

Table1: Distribution of variables related to pregnancy and delivery, according to housing área, in the municipality of Rio Branco - Acre, 2007-2008.

\begin{tabular}{|c|c|c|c|c|c|}
\hline \multirow[t]{2}{*}{ Variables } & \multicolumn{2}{|c|}{ Urban Zone } & \multicolumn{2}{|c|}{ Rural zone } & \multirow[t]{2}{*}{$p$ value } \\
\hline & $\mathbf{n}$ & $(\%)$ & $\mathbf{n}$ & $(\%)$ & \\
\hline \multicolumn{6}{|l|}{ Birth Local } \\
\hline Public hospital & 540 & 90,0 & 45 & 96,9 & \multirow{3}{*}{0,066} \\
\hline Private hospital & 58 & 9,3 & - & - & \\
\hline Home & 04 & 0,7 & 01 & 3,1 & \\
\hline \multicolumn{6}{|l|}{ Birth type } \\
\hline Normal & 361 & 61,6 & 33 & 71,5 & \multirow{2}{*}{0,008} \\
\hline Ceasarean & 240 & 38,4 & 13 & 28,5 & \\
\hline \multicolumn{6}{|c|}{ Who made the delivery } \\
\hline Doctor & 419 & 70,0 & 27 & 64,6 & \multirow{3}{*}{0,171} \\
\hline Nurse & 117 & 17,6 & 06 & 11,9 & \\
\hline Midwife & 65 & 12,4 & 13 & 23,5 & \\
\hline \multicolumn{6}{|l|}{ Activity } \\
\hline Not payed & 384 & 63,8 & 42 & 94,3 & \multirow{2}{*}{0,015} \\
\hline Payed & 217 & 36,2 & 04 & 5,7 & \\
\hline \multicolumn{6}{|l|}{ Children } \\
\hline $1-2$ & 340 & 55,0 & 25 & 55,6 & \multirow{3}{*}{0,039} \\
\hline $3-4$ & 190 & 33,6 & 10 & 17,5 & \\
\hline$\geq 5$ & 72 & 11,4 & 11 & 26,9 & \\
\hline
\end{tabular}

Age at first pregancy 


\begin{tabular}{|c|c|c|c|c|c|}
\hline 07-19 & 411 & 69,9 & 32 & 65,2 & \multirow{3}{*}{0,309} \\
\hline $20-28$ & 174 & 28,1 & 14 & 34,8 & \\
\hline 29-37 & 15 & 2,0 & - & - & \\
\hline \multicolumn{6}{|c|}{ Prenatal appointments } \\
\hline $1-3$ & 42 & 7,8 & 06 & 10,2 & \multirow{3}{*}{0,001} \\
\hline $4-5$ & 120 & 19,4 & 20 & 44,7 & \\
\hline$\geq 6$ & 440 & 72,8 & 20 & 45,1 & \\
\hline \multicolumn{6}{|c|}{ Child death $\leq 5$ years } \\
\hline Yes & 59 & 10,4 & 09 & 20,8 & \multirow{2}{*}{0,003} \\
\hline No & 541 & 89,6 & 37 & 79,2 & \\
\hline \multicolumn{6}{|c|}{ Age at last pregnancy } \\
\hline $13-20$ & 168 & 26,7 & 14 & 34,2 & \multirow{4}{*}{0,008} \\
\hline $21-28$ & 277 & 46,4 & 20 & 42,8 & \\
\hline 29-39 & 144 & 26,0 & 08 & 18,4 & \\
\hline $40-46$ & 10 & 0,9 & 02 & 4,6 & \\
\hline
\end{tabular}

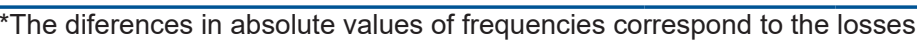

of the interviewees reported the occurrence of death in a child younger than 5 years. These prevalence rates were $65.0 \%$ and $20.9 \%$, respectively, in rural areas.

The prevalence of caesarean delivery (Table 2) in women with less than 5 years of schooling was $25.6 \%$, which was increased to $48.3 \%$ in those with $10-15$ years of schooling $(p=0.001)$. Similarly, caesarean deliveries differed according to strata, performed in $32.1 \%$ of women who underwent 1-3 prenatal consultations and in $37.5 \%$ who had six or more consultations. In regard to the parity

Table 2: Prevalence of normal and caesarean deliveries according to the selected maternal variables in the city of Rio Branco - Acre, $2007-2008$.

\begin{tabular}{|c|c|c|c|c|c|c|c|}
\hline \multirow{2}{*}{$\begin{array}{l}\text { Variables } \\
\begin{array}{l}\text { Maternal schooling } \\
\text { (years) }\end{array}\end{array}$} & \multirow{2}{*}{$\begin{array}{c}\text { Categories } \\
0-4\end{array}$} & \multicolumn{2}{|c|}{$\begin{array}{c}\text { Normal delivery } \\
\mathbf{n}\end{array}$} & \multicolumn{2}{|c|}{$\begin{array}{c}\text { Ceasarean delivery } \\
\mathrm{n}(\%)\end{array}$} & \multirow{2}{*}{$\begin{array}{c}\begin{array}{c}\text { RP Ceasarean } \\
\text { delivery }\end{array} \\
0,53(0,35-0,80)\end{array}$} & \multirow{2}{*}{$\begin{array}{c}\text { RP adjusted* } \\
0,85(0,60-1,21)\end{array}$} \\
\hline & & 84 & 74,4 & 27 & 25,6 & & \\
\hline & $5-9$ & 186 & 71,9 & 77 & 28,1 & $0,58(0,42-0,79)$ & $0,86(0,60-1,24)$ \\
\hline & $10-15$ & 124 & 51,7 & 149 & 48,3 & 1,00 & 1,00 \\
\hline \multicolumn{8}{|l|}{ Maternal age (years) } \\
\hline & $14-24$ & 177 & 67,3 & 96 & 32,7 & $0,91(0,77-1,09)$ & $0,63(0,47-0,83)$ \\
\hline & $25-34$ & 171 & 64,4 & 116 & 35,6 & 1,00 & 1,00 \\
\hline & $\geq 35$ & 46 & 66,5 & 41 & 33,5 & $0,94(0,59-1,49)$ & $1,00(0,79-1,25)$ \\
\hline \multicolumn{8}{|l|}{ Appointments } \\
\hline & $1-3$ & 36 & 67,9 & 12 & 32,1 & $0,85(0,36-2,01)$ & $1,03(0,49-2,17)$ \\
\hline & $4-5$ & 96 & 72,1 & 44 & 27,9 & $0,74(0,42-1,29)$ & $0,97(0,50-1,85)$ \\
\hline & $\geq 6$ & 262 & 62,5 & 197 & 37,5 & 1,00 & 1,00 \\
\hline \multicolumn{8}{|l|}{ Skin colour } \\
\hline & Black & 47 & 69,3 & 23 & 30,7 & $0,54(0,35-0,82)$ & $0,71(0,39-1,27)$ \\
\hline & Mixed & 289 & 69,9 & 171 & 30,1 & $0,53(0,34-0,82)$ & $0,62(0,38-1,01)$ \\
\hline & White & 58 & 43,4 & 58 & 56,6 & 1,00 & 1,00 \\
\hline \multicolumn{8}{|l|}{ Home zone } \\
\hline & Rural & 33 & 71,5 & 13 & 28,5 & $0,74(0,60-0,90)$ & $1,04(0,69-1,57)$ \\
\hline & Urban & 361 & 61,6 & 240 & 38,4 & 1,00 & 1,00 \\
\hline \multicolumn{8}{|l|}{ Place of birth } \\
\hline & $\begin{array}{l}\text { Public } \\
\text { hospital }\end{array}$ & 376 & 67,8 & 208 & 32,2 & 1,00 & 1,00 \\
\hline & Home & 5 & 100 & - & - & - & - \\
\hline & $\begin{array}{l}\text { Private } \\
\text { hospital }\end{array}$ & 13 & 20,4 & 45 & 79,6 & $2,47(2,03-3,00)$ & $1,77(1,41-2,21)$ \\
\hline \multicolumn{8}{|l|}{ Children } \\
\hline & $1-2$ & 193 & 56,5 & 171 & 43,5 & 1,00 & 1,00 \\
\hline & $3-4$ & 137 & 70,3 & 62 & 29,7 & $0,68(0,49-0,93)$ & $0,62(0,44-0,87)$ \\
\hline & $\geq 5$ & 64 & 88,1 & 19 & 11,9 & $0,27(0,82-0,91)$ & $0,25(0,77-0,86)$ \\
\hline
\end{tabular}

\footnotetext{
*Prevalence ratio adjusted for age, education, number of prenatal appointments, maternal skin colour, home zone, place of birth and number of children.
} 
distribution, caesarean deliveries were reported in $43.5 \%$ of mothers with one or two children, $29.7 \%$ of those with three or four children, and $11.9 \%$ of mothers with five or more children $(\mathrm{p}<0.001)$. The adjusted prevalence ratio for mothers with five or more children versus those with one or two children was 0.25 (95\% CI [0.77, 0.86]). The proportion of caesarean deliveries in private institutions was $79.6 \%$, with $32.2 \%$ in public hospitals, with an adjusted prevalence ratio of 1.77 (95\% CI [1.41, 2.21]).
The prevalence of caesarean delivery in mothers with less than 5 years of schooling was $25.6 \%$, performed in $28.1 \%$ of women with $5-9$ years and $48.3 \%$ of those with 10 or more years of schooling $(\mathrm{p}<0.001$; Table 2$)$.

Table 3 shows that arterial hypertension during puerperium was observed in $71.1 \%$ of caesarean deliveries and $28.9 \%$ of normal deliveries $(\mathrm{p}=0.001)$.

The requirement for hospitalisation during puerperium was reported by $9.5 \%$ of women under 25

Table 3: Distribution of frequencies of selected postpartum complications, according to type of delivery, in the city of Rio Branco - Acre, $2007-2008$.

\begin{tabular}{|c|c|c|c|c|c|}
\hline \multirow[t]{2}{*}{ Complications } & \multicolumn{2}{|c|}{ Normal Delivery* } & \multicolumn{2}{|c|}{ Caesarean Delivery* } & \multirow[t]{2}{*}{$p$ value } \\
\hline & $\mathbf{n}$ & $\%$ & $\mathbf{n}$ & $\%$ & \\
\hline \multicolumn{6}{|l|}{ Haemorrhage } \\
\hline Yes & 28 & 70,1 & 22 & 29,9 & \multirow{2}{*}{0,614} \\
\hline No & 360 & 65,4 & 228 & 34,6 & \\
\hline \multicolumn{6}{|l|}{ Fever } \\
\hline Yes & 43 & 63,6 & 28 & 36,4 & \multirow{2}{*}{0,549} \\
\hline No & 348 & 66,4 & 221 & 33,6 & \\
\hline \multicolumn{6}{|l|}{ Convulsion } \\
\hline Yes & 04 & 48,3 & 04 & 51,7 & \multirow{2}{*}{0,337} \\
\hline No & 386 & 65,9 & 246 & 34,1 & \\
\hline \multicolumn{6}{|l|}{ Psychic dist. } \\
\hline Yes & 54 & 63,7 & 46 & 36,3 & \multirow{2}{*}{0,642} \\
\hline No & 336 & 66,2 & 204 & 33,8 & \\
\hline \multicolumn{6}{|l|}{ Hypertension } \\
\hline Yes & 21 & 28,9 & 34 & 71,1 & \multirow{2}{*}{0,001} \\
\hline No & 370 & 68,1 & 216 & 31,9 & \\
\hline \multicolumn{6}{|l|}{ Hospitalization } \\
\hline Yes & 18 & 64,1 & 31 & 35,9 & \multirow{2}{*}{0,912} \\
\hline No & 372 & 66,0 & 218 & 34,0 & \\
\hline
\end{tabular}

*The differences in the absolute values of the frequencies correspond to the losses

years of age, $4.2 \%$ of those aged 25 to 34 years, and $21.2 \%$ of mothers aged 35 years or older $(\mathrm{p}=0.005$; Table 4$)$.

Postpartum hypertension was $71.1 \%$ in mothers who underwent caesarean delivery, with an adjusted prevalence ratio of $3.90 \quad(95 \%$ CI $[2.00,7.61])$. Hypertension also affected $60.3 \%$ of women between the ages of 14 and 24 years, with an adjusted prevalence ratio of 2.2 (95\% CI [1.01, 4.80]; Table 5).

Table 4: Frequency distribution of postpartum complications, according to the selected maternal variables, in the city of Rio Branco - Acre, $2007-2008$

\begin{tabular}{|c|c|c|c|c|c|c|c|c|c|c|}
\hline \multirow[t]{2}{*}{ Variables } & \multicolumn{2}{|c|}{ Fever* } & \multicolumn{2}{|c|}{ Haemorrhage * } & \multicolumn{2}{|c|}{ Hypertension* } & \multicolumn{2}{|c|}{ Psychic dist. ${ }^{*}$} & \multicolumn{2}{|c|}{ Hospitalization } \\
\hline & $\mathbf{N}$ & $(\%)$ & $\mathbf{N}$ & $(\%)$ & $\mathbf{N}$ & $(\%)$ & $\mathbf{N}$ & $(\%)$ & $\mathbf{N}$ & $(\%)$ \\
\hline \multicolumn{11}{|l|}{ Schooling (years) } \\
\hline $0-4$ & 15 & 9,6 & 10 & 3,7 & 09 & 3,3 & 12 & 7,6 & 10 & 3,5 \\
\hline $5-9$ & 28 & 6,5 & 16 & 6,3 & 18 & 2,9 & 52 & 16,6 & 19 & 13,4 \\
\hline $10-15$ & 29 & 8,9 & 24 & 8,3 & 28 & 11,1 & 37 & 17,6 & 20 & 5,6 \\
\hline$p$ value & \multicolumn{2}{|c|}{0,617} & \multicolumn{2}{|c|}{0,357} & \multicolumn{2}{|c|}{0,102} & \multicolumn{2}{|c|}{0,283} & \multicolumn{2}{|c|}{0,092} \\
\hline \multicolumn{11}{|l|}{ Age (years) } \\
\hline $14-24$ years & 33 & 10,3 & 20 & 8,9 & 25 & 8,1 & 37 & 15,1 & 16 & 9,5 \\
\hline $25-34$ years & 35 & 7,5 & 24 & 4,5 & 23 & 3,7 & 47 & 13,8 & 23 & 4,2 \\
\hline$\geq 35$ years & 03 & 2,1 & 05 & 4,3 & 07 & 4,7 & 17 & 17,1 & 10 & 21,2 \\
\hline$p$ value & \multicolumn{2}{|c|}{0,066} & \multicolumn{2}{|c|}{0,241} & \multicolumn{2}{|c|}{0,186} & \multicolumn{2}{|c|}{0,796} & \multicolumn{2}{|c|}{0,050} \\
\hline \multicolumn{11}{|l|}{ Children } \\
\hline $1-2$ & 36 & 7,9 & 24 & 7,0 & 30 & 6,4 & 51 & 14,5 & 22 & 8,8 \\
\hline $3-4$ & 27 & 9,2 & 19 & 6,8 & 22 & 7,5 & 35 & 13,2 & 20 & 6,6 \\
\hline$\geq 5$ & 08 & 6,7 & 07 & 3,7 & 03 & 1,0 & 15 & 17,6 & 07 & 10,1 \\
\hline$p$ value & \multicolumn{2}{|c|}{0,807} & \multicolumn{2}{|c|}{0,609} & \multicolumn{2}{|c|}{0,037} & \multicolumn{2}{|c|}{0,742} & \multicolumn{2}{|c|}{0,522} \\
\hline
\end{tabular}

*The differences in the absolute values of the frequencies correspond to the losses 
Table 5: Prevalence of postpartum hypertension according to the selected maternal variables in the municipality of Rio Branco - Acre, 2007-2008

\begin{tabular}{|c|c|c|c|c|c|}
\hline \multirow[t]{2}{*}{ Variables } & \multirow[t]{2}{*}{ Categories } & \multicolumn{2}{|c|}{ Hypertension } & \multirow[t]{2}{*}{ RP Hypertension } & \multirow{2}{*}{$\begin{array}{l}\text { RP adjusted* } \\
\text { Hypertension }\end{array}$} \\
\hline & & $\mathrm{n}$ & $(\%)$ & & \\
\hline \multirow[t]{2}{*}{ Birth type } & Normal & 21 & 28,9 & 1,00 & 1,00 \\
\hline & Cesárea & 34 & 71,1 & $4,73(1,77-12,59)$ & $3,90(2,00-7,62)$ \\
\hline \multicolumn{6}{|c|}{ Maternal age } \\
\hline & 14-24 anos & 25 & 60,3 & $2,18(0,76-6,24)$ & $2,20(1,01-4,80)$ \\
\hline & 25-34 anos & 23 & 30,1 & 1,00 & 1,00 \\
\hline & $\geq 35$ anos & 07 & 9,6 & $1,26(0,39-4,05)$ & $0,88(0,28-2,73)$ \\
\hline \multicolumn{6}{|c|}{ Maternal skin colour } \\
\hline & Negra & 06 & 5,8 & $0,11(0,11-1,07)$ & $0,20(0,24-1,66)$ \\
\hline & Parda & 35 & 51,5 & $0,25(0,51-1,29)$ & $0,40(0,12-1,29)$ \\
\hline & Branca & 14 & 42,7 & 1,00 & 1,00 \\
\hline \multicolumn{6}{|c|}{ Home zone } \\
\hline & Rural & 01 & 23,9 & 1,00 & 1,00 \\
\hline & Urbana & 54 & 76,1 & $2,45(0,80-7,49)$ & $2,06(0,60-7,03)$ \\
\hline
\end{tabular}

${ }^{*}$ Prevalence ratio adjusted for age, type of delivery, skin colour and home area

\section{DISCUSSION}

The sample included in this study can be considered representative of the population of mothers of children under 5 years old in Rio Branco as it was performed as a population-based survey, supported by the low rate of loss and refusals.

The findings of the present study indicate that there is a higher probability of performing a caesarean delivery in women who give birth at private hospitals or in maternity hospitals, in those with a higher level of educational, in women who define themselves as white, those who live in urban areas and who are older than 25 years.

The prevalence of caesarean deliveries in public and private institutions was high in relation to the $15 \%$ prevalence reported by the World Health Organization (WHO). However, a higher prevalence has also been reported in other studies. In Santa Catarina, the prevalence of caesarean section was found to be $61.3 \%$ in public institutions and $100 \%$ in private institutions ${ }^{10,11}$.

A national survey ${ }^{4}$ carried out with 23,894 puerperae supports the findings of the present investigation, in which it was evidenced that caesarean section was less frequent among non-white public sector users with lower levels of education and who were multiparous. This reinforces a pattern previously described in Brazil ${ }^{12}$.

The average number of children per woman in Rio Branco is higher than the national level and that of the North region, which is 1.8 and 2.28 children, respectively ${ }^{3}$.

It is worth highlighting the universality of hospital delivery, especially public hospitals. Furthermore, we found a smaller proportion of births in Acre compared to that reported in the North region of $7.5 \% \%^{3}$.

The vast majority of deliveries were performed by a formally qualified professional (physician or nurse). However, a significant proportion of women (12.4\% in urban areas and $23.5 \%$ in rural areas) had their births attended by traditional birth attendants, especially those with lower levels of education, those living in rural areas of the municipality and those who had undergone fewer prenatal consultations. This is higher than the prevalence of births performed by traditional midwives in the North and Northeast of $5.8 \%$ and $3.6 \%$, respectively ${ }^{3}$.

As for complications experienced by the studied women during the postpartum period, psychiatric disorders (mental/emotional problems, depression, loss of judgment) had the highest prevalence. According to the literature, the pregnancy-puerperal period is associated with a high incidence of psychiatric disorders, affecting 10-20\% of puerperal women ${ }^{13}$. These disorders, known as maternal or postpartum depression, involve an emotional, humoral and reactive disorder during the puerperium period ${ }^{14}$.

The prevalence of reports of hypertension during puerperium was higher in women who underwent caesarean delivery. Although the presence of hypertension in pregnancy does not necessarily require a caesarean delivery, several studies have shown that hypertension is one of the most cited reasons for performing caesarean deliveries as hypertensive syndromes are the leading cause of maternal death in Brazil, accounting for $15 \%$ of deaths ${ }^{15}$.

The association between advanced age and caesarean section reported in several studies, such as in Santa Catarina ${ }^{10,16}$, was not found in this survey. We observed a higher prevalence of caesarean section in young women.

The results of the "Nascer no Brasil" study showed a high proportion of caesarean sections among adipose primiparas $(40 \%)$. The factors most strongly associated with caesarean section being considered a safer delivery method included childbirth funded by the private sector, the same health professional attending prenatal consultations and childbirth, and presentation of clinical indications of risk and intercurrences during pregnancy. Adolescent pregnancy remains a topic of discussion in the 
area of reproductive health, and the proportion of surgical delivery in these women is worrying due to early exposure to the effects of caesarean ${ }^{17}$. The findings of this survey also indicate that, according to the geographic region analysis, the chance of a pregnancy resulting in caesarean section is higher in the North region when compared to other regions of the country, probably due to the low coverage provided by health plans and the high caesarean rate in the public and private services of this region ${ }^{4}$.

It was found that a higher prevalence of births were attended by traditional midwives in women aged 35 years or over. This is worrying as it is known that pregnancies in this age group are considered riskier because they are associated with a higher incidence of maternal complications, such as greater weight gain, obesity, gestational diabetes, hypertension and preeclampsia ${ }^{15}$.

The association between a higher education level and caesarean section found in the present study is in line with other studies in the literature conducted in Chile and Santa Catarina ${ }^{10,16}$.

Most births took place in public institutions. The groups with the highest number of childbirths in public institutions included pregnant women aged 14 to 24 years, those with lower levels of schooling, self-reported black skin colour, those living in rural areas of the city and having had fewer prenatal consultations.

It is worth noting the observed prevalence of home births in the sample, which were more frequent in women in the rural areas of the municipality and in those with lower schooling.

Taken together, the results observed in this study reveal the need to expand the debate on caesarean deliveries, the prevalence of which are much higher in Rio Branco than that recommended by the WHO. This high rate of caesarean section deliveries are associated with important postpartum complications such as prolonged hospitalisation of puerperal, an increased cost of care, and causing controllable damage to the health of the puerperal population, such as those described in this research.

In order to improve assistance during the pregnancypuerperal cycle, as well as the quality of life of the mother- baby binomial, interventions in the field of obstetric care should be guided based on scientific evidence in both public and private institutions.

The findings of the present study highlight an issue related to the high number of caesarean deliveries performed in the city of Rio Branco, as well as the repercussions for these women during the puerperal phase, with arterial hypertension occurring in $71.1 \%$ of those who underwent caesarean section.

The increase in the incidence of caesarean section represents an important public health problem, especially in Brazil, where caesarean rates are already unacceptably high and may contribute to an increase in the rates of maternal and perinatal morbidity and mortality.

There is a clear need to further study and discuss this public policy issue in Rio Branco, Acre, Brazil, in an attempt to develop strategies to increase access to qualified prenatal care and provide a link between outpatient care and childbirth.

Some limitations of the present investigation should be considered. This study was performed as a survey in which data were collected from pregnancies over the past 5 years, which may generate information and memory bias.

\section{Acknowledgements}

Thanks to our heartfelt thanks to Prof. Sérgio Koifman ("In Memoriam"), for his invaluable contribution to the design, planning and construction of the research project, data collection, analysis and interpretation of the data.

The realization of this investigation was made possible through the academic collaboration established between the program of Masters in collective health of the Federal University of Acre and the program of post-graduation in public health and environment of Fundação Oswaldo Cruz, the which has been supported with the resources of the National Council of Scientific Research and development-CNPq (edictal blanket UFACFIOCRUZ, Case No. 620024/2008-9); CAPES (Programs PROCAD-NF 1442/2007 and PROCAD-NF 2557/2008) and Ministry of Health.

\section{REFERENCES}

1. Lawn JE, Cousens S, Zupan K; Lancet Neonatal Survival Steering Team. 4 million neonatal deaths: When? Where? Why? Lancet. 2005;365(9462):891-900. DOI: http://dx.doi.org/10.1016/S0140-6736(05)71048-5

2. World Health Organization (WHO). Health and the milennium development goals. Geneva: World Health Organization, 2005.

3. Brasil. Centro Brasileiro de Análise e Planejamento. Pesquisa Nacional de Demografia e Saúde da Criança e da Mulher: PNDS 2006. Dimensões do processo reprodutivo e da saúde da criança. Brasília: Ministério da Saúde, 2009.

4. Leal MC, Pereira APE, Domingues RMSM, Theme Filha MM, Dias MAB, Nakamura-Pereira M, et al. Intervenções obstétricas durante o trabalho de parto e parto em mulheres brasileiras de risco habitual. Cad Saúde Pública. 2014;30(suppl 1):S17-32. DOI: http://dx.doi.org/10.1590/0102-311X00151513

5. Roberts CL, Tracy S, Peat B. Rates of obstetric intervention among private and public patients in Australia: population based descriptive study. BMJ. 2000;321(7254):137-41. DOI: https://dx.doi.org/10.1136/bmj.321.7254.137

6. Cecatti JG. Saúde da mulher: Enfoque da evidência científica para a prevenção da morbidade e mortalidade materna. Rev Bras Saude Mater Infant. 2005;5(1):9-11. 
7. World Health Organization (WHO). Mannaging complications in pregnancy and childbirth: a guide for midwives and doctors. Geneva: WHO/ UNFPA/ UNICEF/ World Bank, 2000.

8. Viggiano MB, Viggiano MGC, Souza E, Camano L. Necessidades de cuidados intensivos em maternidade pública terciária. Rev Bras Ginecol Obstet. 2004; 26(4):317-23. DOI: http://dx.doi.org/10.1590/S0100-72032004000400009

9. Starrs A. The safe motherhood action agenda: priorities for the next decade. Proceedings. Washington, DC: World Bank, 1997.

10. World Health Organization. Appropriate technology for birth. Lancet. 1985; 2(84532):436-67. DOI: https://doi.org/10.1016/S0140-6736(85)92750-3

11. Bofante TM, Silveira GC, Sakae TM, Sommacal LF, Fedrizzi EN. Fatores associados à preferência pela operação cesariana entre puérperas de instituição pública e privada. Arq Catarin Med. 2009;38(1):26-32.

12. Domingues RMSM, Dias MAB, Nakamura-Pereira M, Torres JA, d'Orsi E, Pereira APE, et al. Processo de decisão pelo tipo de parto no Brasil: da preferência inicial das mulheres à via de parto final. Cad Saude Publica. 2014; 30(suppl1): S101-16. DOI: http://dx.doi.org/10.1590/0102-311X00105113

13. Félix GMA, Gomes APR, França PS. Depressão no ciclo gravídico-puerperal. Comun Ciencias Saude. 2008;19(1):51-60.

14. Holmes, DS. Psicologia dos transtornos mentais. 2ed. Porto Alegre: Artmed; 2001.

15. Queiroz MVO, Jorges MSB, Marques JF, Cavalcante AM, Moreira KAP. Indicadores de qualidade da assistência ao nascimento baseado na satisfação de puérperas. Texto Contexto Enferm. 2007;16(3):479-87. DOI: http://dx.doi.org/10.1590/S0104-07072007000300014

16. Potter JE, Berquo E, Perpetuo IH, Leal OF, Hopkins K, Souza MR, et al. Unwanted caesarean sections among public and private patients in Brazil: prospective study. BMJ. 2001;323(7322):1155-8. DOI: https://dx.doi.org/10.1136/bmj.323.7322.1155

17. Gama SGN, Viellas EF, Schilithz AOC, Theme Filha MM, Carvalho ML, Gomes KRO, et al. Fatores associados à cesariana entre primíparas adolescentes no Brasil, 2011-2012. Cad Saude Publica. 2014; 30(suppl 1): S117-27. DOI: http://dx.doi.org/10.1590/0102-311X00145513

\section{Resumo}

Introdução: A maternidade pode estar associada a riscos para a saúde da mulher e da criança, de forma que uma assistência especializada durante a gravidez, parto e puerpério contribuem para minimizar as complicações para o binômio mãe-bebê.

Objetivo: Analisar as características do parto e pós-parto em Rio Branco em relação aos aspectos demográficos, sociais e reprodutivos.

Método: Estudo transversal de base populacional realizado durante 2007-2008 através de amostragem populacional por conglomerados em duas etapas (setores censitários e domicílios), sendo entrevistadas 552 mães de crianças de zero a cinco anos.

Resultados: Das 552 mães entrevistadas, a maioria era constituída por multíparas (79,6\%). Cerca de $70 \%$ das gestações ocorreram em menores de 20 anos de idade. A prevalência de cesarianas foi de $38,4 \%$ nas mães da zona urbana e de $28,5 \%$ nas que moravam na zona rural, sendo maior nas mulheres assistidas em instituições privadas, que se auto definiram como de cor branca e com maior nível educacional. Quanto às complicações do período puerperal as mulheres que foram submetidas a partos cesáreas apresentaram uma maior prevalência de hipertensão $(71,1 \%)$, sendo observada uma razão de prevalência ajustada de 3,90 (IC 95\%: 2,00-7,61).

Conclusão: $O$ alto índice de gestação na adolescência e a hipertensão arterial sendo a principal complicação no pós-parto cesárea, dados que merecem atenção e que devem ser observados na assistência prestada no município de Rio Branco.

Palavras-chave: parto normal, cesárea, período pós-parto.

๑The authors (2018), this article is distributed under the terms of the Creative Commons Attribution 4.0 International License (http://creativecommons.org/licenses/by/4.0/), which permits unrestricted use, distribution, and reproduction in any medium, provided you give appropriate credit to the original author(s) and the source, provide a link to the Creative Commons license, and indicate if changes were made. The Creative Commons Public Domain Dedication waiver (http://creativecommons.org/publicdomain/zero/1.0/) applies to the data made available in this article, unless otherwise stated. 